\title{
The ecotourism-extraction nexus and its implications for the long-term sustainability of protected areas: what is being sustained and who decides?
}

\author{
Wendy Hill ${ }^{1}$ \\ Jason Byrne \\ Fernanda de Vasconcellos Pegas \\ Griffith University, Australia
}

\begin{abstract}
Some conservationists assert that multiple-use protected areas can accommodate competing claims for resource use, including extraction (e.g. mining and fisheries) and in-situ use (e.g. ecotourism). This is despite a growing number of studies showing how communities struggling with poverty, isolation, economic stagnation and environmental degradation experience limited benefits from ecotourism. This paper examines opposing claims over resource use (mining and ecotourism) in a World Heritage site in El Vizcaíno Biosphere Reserve, Mexico. It explores the idea that institutional processes can dis-incentivize both income generation from ecotourism and conservation if inequitable access to resources is not remedied. The article illustrates how ecotourism's contribution to socio-economic development of local communities can be circumscribed by: (1) the historical patterns of resource use; (2) misdirected interventions by state actors; (3) duplicitous actions of multi-national corporations, and (4) opaque governance processes with limited accountability. Findings support arguments that the capacity of ecotourism to reduce inequitable access to resources is limited and highlight why ecotourism cannot substitute for genuine institutional reform in protected area designation and management.
\end{abstract}

Key words: ecotourism, participation, El Vizcaíno Biosphere Reserve, Mexico, neoliberal conservation, sustainable development, equity

\section{Résumé}

Certains protecteurs de l'environnement affirment que l'aménagement polyvalent de zones protégées permet des revendications concurrentes dans l'exploitation des ressources, y compris dans l'extraction minière et la pêche, ainsi que l'utilisation in situ (écotourisme). Celles-ci est malgré le fait que de nombreuses études démontrent que les communautés aux prises avec la pauvreté, l'isolement, la stagnation économique et la dégradation de l'environnement bénéficient de façon très limitée de l'écotourisme. Cet article examine les revendications conflictuelles à l'égard de l'utilisation des ressources dans le site du patrimoine mondial de la biosphère El Vizcaíno au Mexique. Il explore l'idée que si l'inégalité dans l'accès aux ressources n'est pas remédiée, les processus institutionnels peuvent empêcher à la fois la génération de revenus de l'écotourisme et la préservation de l'environnement. Cette article examine aussi comment la contribution de l'écotourisme au développement socio-économique est limitée par: (1) le modèle historique de l'exploitation des ressources; (2) les interventions mal dirigées a la part de l'État; (3) la duplicité dans les gestes des sociétés multinationales, et (4) les processus opaques de gouvernance sans obligation de rendre compte. Ces conclusions soutiennent l'argument que la capacité de l'écotourisme à réduire les inégalités dans l'accès aux ressources est limitée. Elles mettent aussi en évidence pourquoi l'écotourisme ne peut pas remplacer une réforme institutionnelle authentique dans l'aménagement et la désignation des zones protégées.

\footnotetext{
${ }^{1}$ Wendy Hill, Doctoral candidate, Griffith University, Gold Coast Campus, Parklands Drive, Southport Qld 4222, Australia. Email: s1098444 "at" griffithuni.edu.au; Dr. Jason Byrne, Associate Professor, Griffith University. Email: jason.byrne "at" griffith.edu.au; Dr. Fernanda de Vasconcellos Pegas, Research Fellow, Griffith University. Email: fernandapegas1 "at" yahoo.com. The authors thank two anonymous referees and the editor for their insights, as well as Elisa Moreno, Debra Valov, Sara Álcala Jiménez, Francisco Grado Villa, Adriana Ruíz and Sylvie Beauregard for feedback, translations, and logistical support. This research was supported by a Griffith University Postgraduate Research Scholarship (062206F). The authors take responsibility for any errors.
} 
Mots clés: l'écotourisme, la participation, la Réserve de la biosphère d'El Vizcaino, Mexique, conservation néolibérale, le développement durable, l'équité

\section{Resumen}

Algunos conservacionistas afirman que las áreas protegidas de múltiples usos, pueden acomodar las reclamaciones competidoras para el uso de los recursos, incluyendo la extracción (por ejemplo, minería y pesca) y conservación in situ (ej. Ecoturismo). Esto es a pesar de un creciente número de estudios que muestran cómo las comunidades luchan contra la pobreza, el aislamiento, el estancamiento económico y la degradación del medio ambiente experiencia limitados beneficios de ecoturismo. Este documento examina las reclamaciones sobre el uso de recursos (minería y ecoturismo) en un sitio del Patrimonio Mundial en la Reserva de la Biosfera El Vizcaíno, México. Se explora la idea de que los procesos institucionales pueden dis-incentivar la generación de ingresos a partir del ecoturismo y la conservación, si la inequidad en el acceso a los recursos no está solucionado. El documento ilustra cómo el ecoturismo su contribución al desarrollo socioeconómico de las comunidades locales pueden estar circunscrito por: (1) los patrones históricos de uso de los recursos; (2) confundió las intervenciones estatales; (3) las deshonestas acciones de corporaciones multinacionales, y (4) la opacidad de los procesos de gobernabilidad con una responsabilidad limitada. Conclusiones apoyan los argumentos de que el fomento del ecoturismo para reducir las desigualdades en el acceso a los recursos es limitado y resaltar por qué el ecoturismo no puede sustituir a una verdadera reforma institucional en el área protegida de designación y gestión.

Palabras clave: el ecoturismo, la participación, la Reserva de la Biosfera del Vizcaíno, México, la conservación neoliberal, el desarrollo sostenible, la equidad

\section{Introduction}

Multiple-use protected areas, such as biosphere reserves, are products of a conceptual shift in conservation policy, based on the twin goals of preserving biodiversity and providing socio-economic development opportunities for local communities (Adams and Hutton 2007; West et al. 2006). Conservation policy is thought to be more likely to succeed if local communities are able to share the economic benefits of environmental protection and management (Wells and McShane 2004; Worboys et al. 2015). Ecotourism has been touted as an ideal mechanism to achieve this goal because it purportedly enables the long-term sustainability of protected areas in developing countries. Ecotourism activities are said to reduce pressure from extractive forms of economic activity (e.g. mining) while simultaneously enabling local people to derive livelihoods from the in-situ use of local ecosystems (Brockington et al. 2006; Büscher and Davidov 2015). Essentially, this is a neoliberal policy where the environment is commodified and valued for its potential economic returns (Castree 2010; Heynen and Robbins 2005). In pursuit of these goals, most governments in developing countries have ecotourism strategies for their protected areas, focused on economic growth - which is thought to lead to employment and foreign exchange earnings and to provide a buffer against volatile markets (Pegas and Castley 2014).

Castree (2010) argues that neoliberlism comprises a philosophy centred on economic liberty, including the belief that capitalist markets should determine decisions that would otherwise be made within the political sphere. Thus, the neoliberalisation of conservation involves processes of management and governance that are increasingly directed towards market-friendly (de)regulation, to promote the growth of third sector groups in environmental protection and management (Castree 2010; Heynen and Robbins 2005). For example, much of the contemporary conservation discourse implies that multiple-use protected areas can accommodate competing claims for resource use, including extractive industries (e.g. agriculture and mining) and in-situ use (ecotourism) (Agrawal and Gibson 1999; Campbell et al. 2007; Hunt et al. 2015). However, a growing number of scholars have begun to critically examine how processes such as privatization and deregulation combine with 'free market' governance practices to produce divergent social and environmental outcomes (Brockington et al. 2008; Duffy 2013; Fletcher and Neves 2012). Such studies are embedded within an overarching body of research examining the interactions of variegated capitalisms and constellations of actors in environmental management (Castree 2010; Heynen et al. 2007; Peck and Tickell 2002). There has been a growing realization that neoliberal policies of environmental management more 
often than not exacerbate environmental degradation and social inequality, leading to calls to decouple conservation and capitalist development (McShane et al. 2011; Minteer and Miller 2011).

Political ecology scholars have been especially vocal in this arena and there is a burgeoning literature on political ecologies of ecotourism (Mostafanezhad et al. 2015; Nepal and Saarinen 2015). Ecotourism is one manifestation of a local community development approach incorporating conservation (Büscher et al. 2012). In fact, ecotourism is viewed by its proponents as an ideal mechanism for in-situ biodiversity conservation using income generation that incorporates the ideals of capitalist economics (Büscher and Fletcher 2015; Fletcher and Neves 2012). Since the 1980s, the Mexican government has embraced a locally inflected neoliberalism (Soederberg et al. 2005) and has attempted to integrate environmental conservation and capitalist development within its burgeoning protected area estate (Haenn et al. 2014). However, inequality has been a long-standing feature of Latin America (Perreault and Martin 2005) and in Mexico's protected areas, progress in addressing socio-economic inequality has been slow (Breunig 2006; Hill et al. 2015; Teichman 2008).

Researchers have increasingly begun to question the rationale and efficacy of neoliberal approaches to conservation and economic development (Büscher and Davidov 2015; Igoe and Croucher 2007). Some have found that projects intended to integrate people inhabiting multiple-use protected areas with conservation efforts are problematic on two counts. First, some projects fail to address social inequality adequately because they do not ensure the equitable redistribution of resources (Durand et al. 2014; Hoffman 2014; Martinez-Reyes 2014). For example, disparities in benefit distribution along multiple axes of difference (e.g. class, gender, ethnicity), can lead to unsustainable resource use (Rocheleau 2008; Sundberg 2004). Strategies to redress this include the targeted release of funds by aid agencies to specific groups, the progressive redistribution of economic benefits to specific stakeholders (e.g. lower income groups, ethno-racial minorities), and the intentional and inclusive involvement of women in environmental management organizations, such as striving for gender equity on governing boards, decision-making panels etc. (Agarwal 2009; Agrawal and Chhatre 2007; Platteau 2004). Second, programs intended to integrate people living in multiple-use protected areas with conservation can set up relationships among financial donors, state agencies and local residents that may entrench unequal power relations and promote economic returns over social and environmental outcomes (Doane 2014; Fletcher and Breitling 2012; McAfee and Shapiro 2010). As an example of this dynamic, Lee (2014) suggests that ecotourism in Mexico's 41 UNESCO listed biosphere reserves has gained political support because it fills a lacuna created by state budget cuts, which inadequately fund conservation.

What has been missing is an understanding of how seemingly incongruent activities such as ecotourism and extractive industries can coexist within protected areas - what Buscher and Davidov (2015) term the 'ecotourism-extraction nexus.' This is an important knowledge gap. The co-location of extractive industries and in-situ resource conservation is common in biodiverse developing countries that are also rich in mineral resources (Büscher and Davidov 2015). Political ecologists recognize that relationships among big-business operations and local resource management institutions are complex and interactive in the context of historically and politically contingent circumstances of protected area designation and management. The internal operations of institutions can be exclusionary, configured by social differences (such as power) and other forms of inequality (e.g. gender) (Hastings 2015; Walker et al. 2007). Moreover, the equitable distribution of costs or benefits across individuals or communities from resource use restrictions is rarely explicitly addressed in conservation and development planning processes (Halpern et al. 2013; Hirsch et al. 2011). This is a potential source of conflict. Much needed are critical analyses of whether multiple-use protected areas can accommodate competing claims for resource use without detrimentally impacting local ecologies, local cultures and local livelihoods. This article seeks to address this knowledge gap. A primary aim of this study was to better understand ecotourism as one manifestation of a local community development approach to neoliberal conservation.

In the article, we use a political ecology approach to examine how protection designations have shaped the viability of competing livelihood options in a World Heritage site in El Vizcaíno Biosphere Reserve, Mexico. Rather than assuming that conservation and development are incongruous, we sought to investigate the role of institutions in configuring access to resources, and whether institutional processes may 
dis-incentivize both income generation from in-situ resource use and conservation of biodiversity and local cultures. We sought to answer two inter-related research questions: (1) how are the competing resource use claims of mining operations and whale watching ecotourism being resolved - especially their differential impacts for local community development (in other words, what is being sustained)? and (2) what processes are in place to ensure that ecotourism delivers equitable outcomes for local communities and are these processes participatory (in other words, who decides)? We conclude by discussing the implications of our findings for conservation practitioners and we suggest some directions for future research.

\section{Methods}

\section{Study area}

The research was carried out in Mexico's largest protected area - El Vizcaíno Biosphere Reserve (2.45 million ha, 24,500 $\mathrm{km}^{2}$ ). The Reserve occupies the central section of the Baja California peninsula, extending from a $5 \mathrm{~km}$ marine buffer zone on the Pacific coast including the Vizcaíno Desert and the San Francisco Mountains in the interior, to the Gulf of California marine buffer zone (INE 2000) (Figure 1). The Reserve was created through a Presidential Decree in 1988 with the National Ecology Institute publishing the management plan in 2000 (INE 2000). Designation of the region was critical for the biodiversity conservation of northwest Mexico, protecting habitat for endangered terrestrial species as well as providing additional protection for gray whales (Eschrichtius robustus), which already had limited protection within the Ojo de Liebre and San Ignacio Lagoons that had been declared as whale sanctuaries in 1972. The two lagoons were listed by UNESCO as The Whale Sanctuary of El Vizcaíno World Heritage Site in 1993 (INE 2000).

Reserve administration is under federal jurisdiction. The National Commission for Natural Protected Areas (CONANP), a regional agency of the Ministry of the Environment and Natural Resources (SEMARNAT), has responsibility for on-site implementation of management and operational plans and biological research. A regional agency of the Federal Attorney General's Office for Environmental Protection (PROFEPA) investigates violations of environmental laws (INE 2000).

\section{Data collection}

Field research in El Vizcaíno Biosphere Reserve, Mexico was undertaken by the first author between October 2012 and February 2015. She has lived part-time on the southern boundary of the Reserve since 2011. A mixed methods approach comprising structured interviews, semi-structured interviews and participant observation was used to obtain information from residents of Ejido Benito Juárez ${ }^{2}$ and stakeholders external to the community (Veal 2011). Ejido Benito Juárez has a concession to conduct whale watching ecotourism in a section of the Ojo de Liebre Lagoon where gray whales come to breed. Participant observation generated data including via attendance at tourism excursions, education seminars, a regional sea turtle conservation conference, and through sharing of outings, meals and celebrations with individuals and families to build rapport. These two methods enabled data triangulation; interview techniques and participant observation are commonly employed for this purpose in field research (Veal 2011).

\footnotetext{
${ }^{2}$ The ejido is a characteristically Mexican land tenure system that was instituted after the Mexican revolution (19101920) to distribute land to poor peasants. It is predominantly used for farming, forestry and, most recently, conservation. Recent legislation provides for dividing and privatizing land into parcels (Martinez-Reyes 2014). Young (1999: 373) described these communities as a "patchwork of individuals and families" struggling to develop individual and collective capacity for economic management.
} 


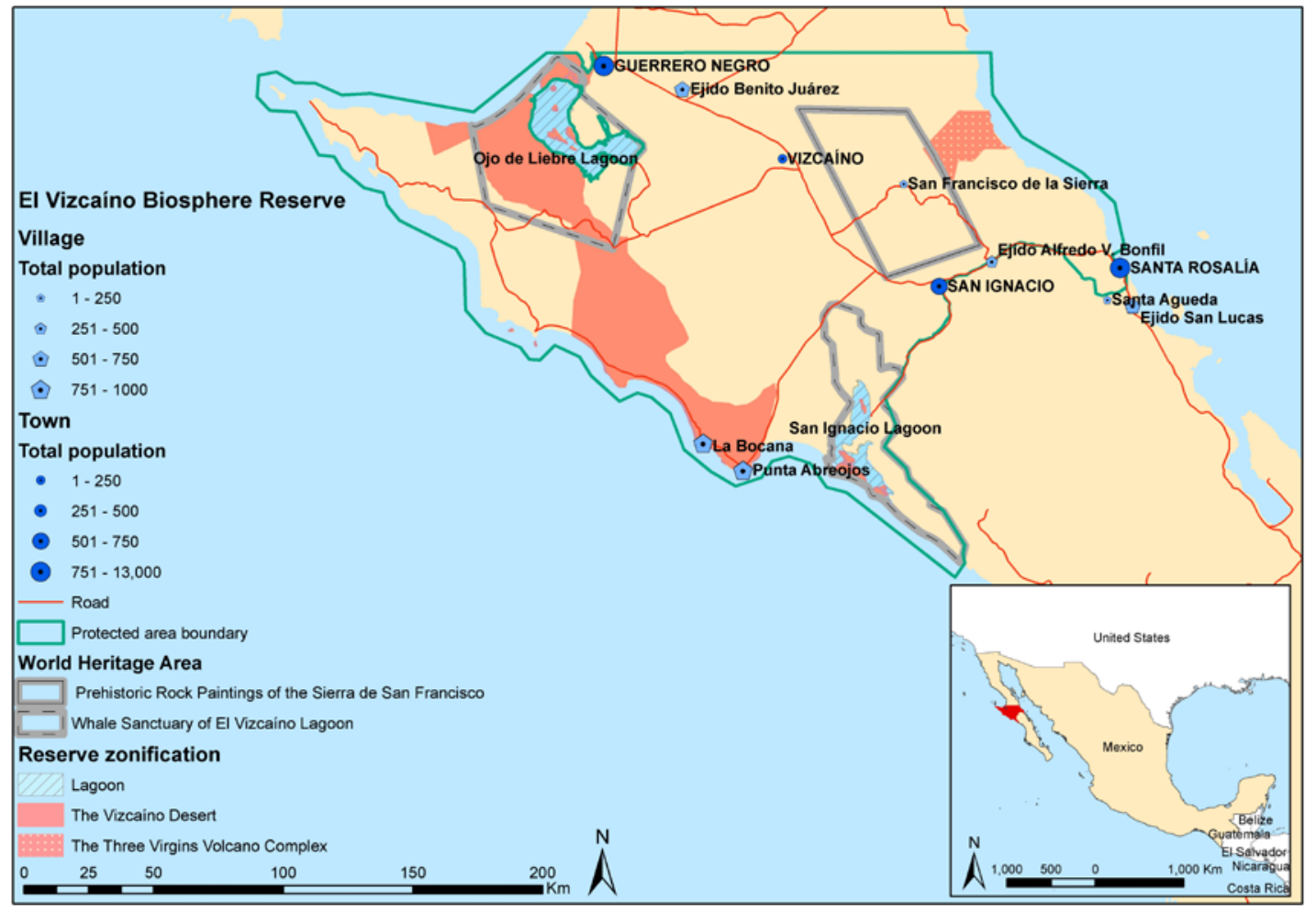

Figure 1: Geographic location of El Vizcaíno Biosphere Reserve, Baja California Sur, Mexico.

These methods were informed by Van Wynsberghe and Khan's (2007) assessment of case studies; they recommend six key steps:

1. Present an intensive and in-depth focus on the specific unit of analysis

2. Provide contextual detail

3. Focus on investigations that do not reduce the context to single cause-and-effect relationships

4. Offer the possibility of generating working hypotheses and describing lessons learned

5. Use multiple data sources and

6. Provide extendibility, so that the findings are potentially applicable to protected areas in other developing countries.

The research occurred in three separate phases: (1) a scoping phase between October 2012 and February 2013 to understand issues and dynamics within the Reserve in general and in particular, ecotourism; (2) structured interviews from November 2013 to February 2014 with 14 residents of Ejido Benito Juárez selected for their knowledge of the operations of the ejido and the ecotourism enterprise and in-depth semistructured interviews with 35 community members and external stakeholders, and (3) follow-up interviews from November 2014 to February 2015 with selected community and external interviewees to verify and cross-validate findings. Potential respondents were provided with verbal background information and an information sheet in Spanish, overviewing the nature of the research. Respondents provided informed 
consent by either signing a consent form or by verbal consent. ${ }^{3}$

The structure of interviews with community members from Ejido Benito Juárez was derived from Pegas et al.'s (2013) examination of community perceptions of sea turtle ecotourism in Brazil. Interviews were administered by the first author and a trained community member and lasted approximately one hour. The trained community member recorded oral responses to the questions in writing. Community respondents were questioned about five key areas: (1) household income and employment from ecotourism and other sources; (2) economic opportunities and constraints; (3) social development opportunities and constraints; (4) conservation opportunities and constraints, and (5) regional development history.

To understand the interplay among actors and how it shapes economic and environmental outcomes, in-depth, semi-structured interviews were held with four additional community members and 31 external informants. These different actors produce constellations of power, that drive symbolic and material conflict over resource use - and social and environmental impacts. Respondents from Ejido Benito Juárez were selected for their specialized knowledge of the ejido and the operations of ecotourism. External respondents included the biosphere Reserve director and staff (three people), academics from the Autonomous University of Baja California Sur, Guerrero Negro campus (UABCS) (four people), students of the Alternative Tourism degree program from UABCS (three people), tourism service providers (11 people), state and municipal employees involved in natural resource management (five people) and staff and volunteers from organizations concerned with regional conservation (five people).

Four of these interviews were recorded using a digital voice recorder and transcribed after the interview. For the others, where interviewees were not comfortable with digital voice recordings, detailed field notes were made as soon as possible after the interview (Veal 2011). Spanish language transcripts were translated into English by the first author who is a fluent Spanish speaker. The interview data were qualitatively analyzed using content analysis and coding to identify key concepts (Sproule 2006). Based on this analysis, selective quotations have been drawn upon to provide important context when discussing the results and to substantiate our claims.

\section{Results}

Results are presented in three parts. The first section describes the development history of the World Heritage site in the context of salt mining and conservation designations. The second section identifies the influence of state and external actors on the collective management of gray whale ecotourism. The third section identifies additional institutional issues that circumscribe conservation and development. Together these findings reveal how the competing resource use claims of mining operations and ecotourism are being resolved (in other words, what is being sustained?), and what processes are in place to ensure that ecotourism delivers equitable outcomes for local communities (in other words, who decides?)?

\section{Development history}

Although the region has had a prolonged human occupation pre-dating Spanish colonization, by the nineteenth century the indigenous populations of the Baja California peninsula were largely wiped out by epidemic diseases attributed to Spanish contact. Settlements in the region are relatively recent, established largely through immigration from mainland Mexico from the 1970s (del Río and Altable Fernández 2011). The town of Guerrero Negro (14,300 people), located adjacent to the World Heritage listed Ojo de Liebre Lagoon whale sanctuary (Figure 1) was founded in 1957 to service evaporative salt production by the multinational company, Exportadora de Sal, S.A. de C.V. (Salt Exporters Inc.), jointly owned by the Mitsubishi Corporation and the Mexican government. Around 35,000 ha $\left(350 \mathrm{~km}^{2}\right)$ of the lagoon's foreshores are used for an industrial complex and salt evaporation in artificial ponds (Figure 2a). Salt mining is a critical source of livelihoods for inhabitants of Guerrero Negro and vitally important for the state economy. The environmental threats from mining include industrial expansion, which transforms extensive tracts of land

\footnotetext{
${ }^{3}$ The interview questions and consent mechanism were approved by Griffith University's human subjects ethics research committee (ENV/11/12/ HREC).
} 
into highly saline evaporation ponds, and contamination of water and soils from salt production waste (Ortega-Rubio et al. 2001a).

The protection designations superimposed over the salt-works development were intended to broaden economic opportunities for local residents through purportedly low impact in-situ resource use (INE 2000). Thus, in addition to its role as a service centre for salt mining, Guerrero Negro is the centre of gray whale ecotourism on the Baja California peninsula. Whale watching is the 'jewel in the crown' among the Reserve's various development programmes. Ecotourism marketing is underpinned by the special circumstance that the whales that come to the lagoon are known for their willingness to approach boats and oftentimes approach close enough for watchers to touch them (Figure 2b; UK Telegraph 2012). Whale ecotourism in the Ojo de Liebre Lagoon is managed under government concessions. Each concession provides a unique area for whale watching during the winter season (December 15th-April 15th) within three different zones where whales come to mate and reproduce (INE 2000). The concession prescribes the number of boats on the water at any one time, the number of boats each day, the number of passengers in each boat and boat operator behavior.
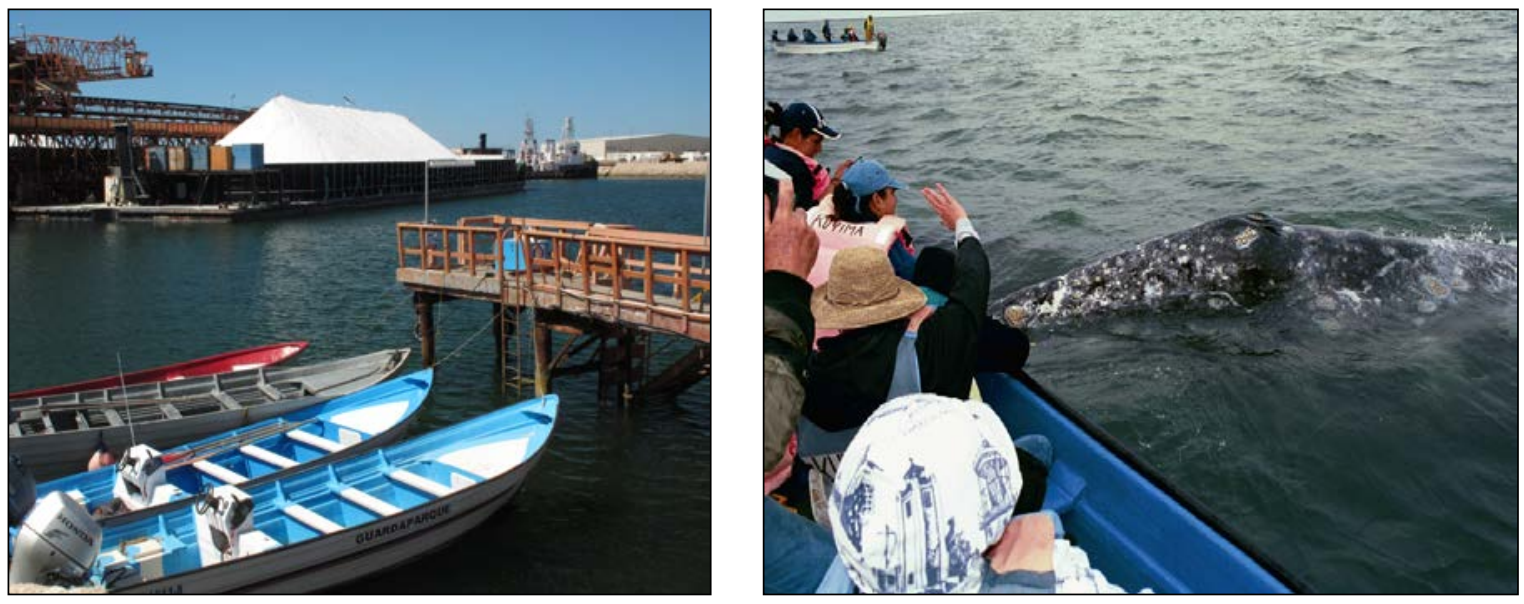

Figure 2: (a) Salt mining barge in the Ojo de Liebre Lagoon in El Vizcaíno Biosphere Reserve, Mexico. Source: Valov (2013) (b) Whale-watching on the Sea of Cortez in Mexico. Source: Valov (2013), with permission.

The rural community of Ejido Benito Juárez was founded in 1972 by a group of 12 men from the mainland Mexican state of Guanajuato. A member of a founding family explained that the settlers were "seeking economic betterment and had petitioned the Mexican government for land on which to live and farm." The outcome of their petition was a decree granting 144,442 ha $\left(1,440 \mathrm{~km}^{2}\right)$ for a 'New Centre of Population Ejido Benito Juárez' to be situated in the isolated and then largely unpopulated Vizcaíno Desert region of the Baja California peninsula. Over time ejido memberships expanded to 90 people all of who were farmers or agricultural workers from the Mexican mainland states of Guanajuato, Jalisco and Zacatecas. A founder explained that: "With the assistance of government development aid programs, land was cleared and demarcated, 13 wells were dug, the first adobe houses were constructed and plots for subsistence and commercial farming were prepared." The families of some founding members subsequently migrated from the mainland.

Small-scale farming in the Vizcaíno Desert region quickly became challenging due to structural and material changes in government economic policy starting in the 1980s and escalating in the 1990s (del Río and Altable Fernández 2011). During this time, Mexico energetically pursued open-market economic policies aimed at encouraging private investment and reducing government involvement in the economy (Babb 2004). Outcomes of these neoliberal economic policy reforms included the insertion of international agricultural consortiums into the Vizcaíno Desert region. According to the Director of the Autonomous University of 
Baja California Sur, the economic viability of agricultural consortiums is underpinned by the importation of poorly paid agricultural workers from mainland Mexico and over-exploitation of the region's precious fossil water, which is being "exported to the United States in the form of tomatoes."

Changes to government economic policy meant that Ejido Benito Juárez was compelled to find new markets for its agricultural products and to compete with agricultural consortiums. A farmer's wife explained some of the challenges:

In the 1980s watermelon crops were very successful with excellent size and weight but buyers bought on credit and failed to pay. Nor was there an authority ejiditarios could turn to for advice or support in dealing with debtors, crop plagues, or rising costs of agricultural production.

Since the ejido's inception, small-scale farming has been marginal. Some individuals support their livelihoods with work from outside of the ejido, mainly through working as laborers or trade people in the town of Guerrero Negro. Efforts to diversify economically coincided with the designation of El Vizcaíno Biosphere Reserve (in 1988) and the Whale Sanctuary of El Vizcaíno World Heritage Site (in 1993) and quickly became aligned with CONANP's intentions to integrate rural communities into sustainable livelihoods including through ecotourism.

However, the principal source of revenue for the ejido presently does not come from farming or ecotourism, but from the salt company, which since 2010 has been paying for the use of ejidal land adjacent to the Ojo de Liebre Lagoon. The land used for artificial salt evaporation ponds are the property of two ejidos, Ejido Benito Juárez and Ejido Gustavo Díaz Ordaz. Almost half of the ponds are situated on the communal lands of Ejido Benito Juárez. Interviews revealed that access to these 16,000 ha $\left(160 \mathrm{~km}^{2}\right)$ has been the subject of political action for decades. According to a founding member of the ejido: "The salt company invaded our land but we residents were paid nothing for the invasion." One interviewee was proud of his key role in establishing and then maintaining the economic viability of the ejido. He pointed out that, in his role as ejidal Secretary, he had led the fight for compensation by heading ejidal delegations to Mexico City to represent their case to the Ministry of the Environment and Natural Resources (SEMARNAT).

In 2010, after five decades of divisive negotiations, Ejido Benito Juárez eventually obtained an agreement with the salt company, which stipulates that each of the 90 ejiditarios annually receives 100,000 pesos (US\$8,000) for the use of communal land. However, as a community resident explained: "The payment made by the salt company is a temporary payment arrangement and not a lease agreement as such." Moreover, the community appears to be divided over the amount of the payment. Some people appear to be quite satisfied, while others are frustrated over what they perceive to be its modest amount compared to profits from salt production. For example, an informant pointed out that "The salt company has been occupying ejidal land since 1972, more than half of which is owned by Ejido Benito Juárez." The informant argued that "daily, more than 15,000 tons of salt are transported out of Guerrero Negro on barges, a cargo worth around US\$75,000. The salt company has been using ejidal land for 59 years, but they have only been paying us anything at all in the last five years."

\section{Stakeholders and ecotourism}

Gray whale ecotourism in the Ojo de Liebre Lagoon Whale Sanctuary is a key conservation and development focus within the Reserve (INE 2000). Pursuant to this, in 1988 Ejido Benito Juárez obtained a concession to conduct whale-watching ecotourism within a zone of the lagoon where whales come to give birth. Whale watching occurred prior to this, in the late 1970s, when a founder of the ejido, Martín Barajas Zambrano, began conducting informal lagoon trips for international tourists who wanted to see the friendly whales. Barajas, along with other people in the community, did not initially perceive whale watching as an economic activity. Barajas provided copies of official documents to demonstrate that in 1974, shortly after the ejido had been founded, he had "petitioned the government to allow him to give tours on the Ojo de Liebre Lagoon." The government responded positively to this petition and based upon Barajas' interest in 
whales and his desire to pass on this knowledge to tourists, he was appointed an honorary caretaker of the Ojo de Liebre Lagoon Whale Sanctuary, which had been declared two years earlier in 1972.

By 2014, five businesses had concessions to operate in the Ojo de Liebre Lagoon. Three are private enterprises operating out of Guerrero Negro, one is owned by a group of three fishing collectives based in Guerrero Negro and the other is owned by Ejido Benito Juárez. Tourism companies based in the United States have been bringing in foreign visitors on package tours to Guerrero Negro to view whales in the Ojo de Liebre Lagoon since the early 1970s (Young 1999). In addition, independent tourists from the United States and Canada oftentimes stop at Guerrero Negro to view whales en route to popular tourist destinations in the south of the Baja California peninsula, and national tourism to the peninsula is increasing. Access to the three separate whale watching boat launch sites is obtained by driving through locked and patrolled gates onto the property occupied by the salt works and past the salt evaporation ponds.

The business operated by Ejido Benito Juárez is known as the Casa Mexicana de la ballena gris (the Mexican home of the gray whale). It operates from a visitor centre on ejidal land on the foreshores of the Ojo de Liebre Lagoon. The visitor centre includes a wharf, a ticket office and a small restaurant that serves simple meals, an audiovisual room for educational presentations, a small gift shop and rest rooms. Along the shoreline are two kilometers of camping area (1.24 miles) with more than 20 sites, 13 of which have simple palm-thatched shelters with the remainder being parking and camping spaces. The business is managed by an administrator and a personnel director who are elected by the ejidal assembly annually. While small day-today decisions are made by the administrator and the personnel director, both are under the direction of the ejido Board of Directors to whom they report regularly. In terms of long-term business goals and strategies, the administrator assesses these needs and then informs the Board of Directors.

Just eleven to thirteen people have opportunities for seasonal employment with the Casa Mexicana. These are the administrator, personnel director, five to seven guides, one person in an office in Guerrero Negro, and the rest are two women and one man working in the ticket office and restaurant. All employees are ejido members or family members. All of the guides are, or have been, fishermen. According to the administrator, "they [men] have the experience with boats that women usually lack. Entrenched gender bias surrounding the role of women in rural Mexico has oftentimes caused managers to overlook the potential for women to contribute to sustainable conservation practices (Durand et al. 2014), evidenced by the administrator's stated claim that "no women have expressed interest in being a guide."

Profits from the business are distributed equally among the 90 members of the ejido after paying salaries, other business expenses and the biosphere reserve fee of 54 pesos (US\$4.50) per visitor. Currently profits are around 3,000 pesos per member (US\$230), which is a little less than 300,000 pesos in total (US\$23,000). The profits have gone to pay Seguro Social contributions (Mexico's healthcare, pension and social security system) for ejido members. Members who do not pay into Seguro Social receive the equivalent amount in cash. For example, if a person has to pay 7,200 pesos per year (US\$570), the ejido pays the portion up to the limit of each member's share of the profits.

In 2014, tourism numbers were around $30 \%$ lower than in 2008, which is likely to be a result of the global financial crisis. This drop in visitation was exacerbated by media coverage in North America about the risks from Mexican drug cartels, including for tourists. According to the administrator, "before 2008 there were around 5,000 tourists visiting the Casa Mexicana each year and it was very common for large caravans of up to 20 recreational vehicles to camp for one or more nights." Data collected by the Reserve management agency demonstrate that client numbers for other whale watching businesses based in Guerrero Negro have recovered from the lows experienced post the global financial crisis.

El Vizcaíno Biosphere Reserve was among 10 reserves financially supported by the Global Environment Facility from 1997 to 2003 (Bath and Putney 2010). Funds were channeled through the Reserve management agency and have been used for ecotourism infrastructure, research within the Reserve, as well as paying the wages of staff members. Ejido Benito Juárez benefitted peripherally from this; however additional financial support appears to have been ad-hoc. Funds to construct the ejido's small administration office in Guerrero Negro in 2003 (at a cost of around 200,000 pesos, US\$16,500) was obtained through credit, with the Reserve management agency assisting in the process of locating sources of credit. Funds to build the visitor centre at the lagoon were provided in 2000 from multiple sources - a Spanish aid agency, the 
Reserve management agency, the Federal Electricity Commission, a banking group and various other local businesses. Members of the ejido were involved in the construction, for which they were paid a wage by the management agency. Beyond this, opportunities to build institutional capacity for ecotourism development and diversification have been limited. The first diploma level course for tourism guides, for example, was only offered recently, in 2014, by the state government.

Interviewees mentioned just one other source of financial support. A women's group made a proposal to SEMARNAT (through the Reserve management agency in Guerrero Negro) in 2006 to implement a recreational trail with education stations for bikes and kayaks on the foreshores and inner waters of the lagoon. The rationale for the proposal was that a trail would provide environmental education and lifestyle enhancement opportunities for Ejido Benito Juárez and for the wider community in Guerrero Negro. The response from SEMARNAT was positive and the women's group received a sustainable development grant in 2006. The interpretive trail was professionally designed and kayaks and bikes were purchased and tested. However, the trail project has been stalled since 2006 and the equipment has 'disappeared.' Again evidencing gender disparities, at the last minute, ejido leaders refused the women permission to use infrastructure at the lagoon. Most recently in 2015, it appears a proposal by one of the women to develop the interpretive trail was ignored by leaders. The Reserve management agency appears to be unconcerned by this situation.

In explaining the non-constructive relationship between ejido leaders and the women's group, a tourism service provider in Guerrero Negro explained his understanding in this way:

In reality cooperation does not happen .... the ejido Board of Directors want all the power for themselves .... Ejidatarios are greedy and expect the government to be always giving them support without having to work for the things that non-ejidatarios have to work for.

Explaining the response of the management agency to the outcomes of the stalled trail project, an informant advised that some staff members expected and had received a financial kickback from those receiving the grant, and thus may be reluctant to be critical.

\section{Conservation among weak institutions}

An overriding problem is that mismanagement and corruption are common by the state and in the private sector in Mexico (Haenn et al. 2014). The encounters of informants from Ejido Benito Juárez with state institutions affected their perceptions of conservation strongly. Some inhabitants expressed concern about the lack of information available about the Reserve's operations. For example "they do not tell us what they are doing"; and "they lack the responsibility to disseminate information." Informants also mentioned the importance of evaluating industrial activities in relation to environmental impacts, stating that:

The governance of the Reserve is inefficient as they do not seek the support of scientific advisors and researchers

They need to create certified environmental monitoring programmes.

The salt company keeps growing and there is no control over the management of its waste or the waste from Guerrero Negro.

Informants were also concerned about the financial management of the municipality. A government employee responsible for managing fisheries in the Ojo de Liebre Lagoon stated that "salaries have not been paid to employees, including myself, for at least 17 months." These perceptions highlight that government institutions in the region are ill-equipped to handle the challenges of conservation within a neoliberal paradigm.

In fact, local peoples' perceptions of mismanagement reflect documented malfeacance and misfeacance in the institutions of government agencies and big business within the Reserve. The municipality of Mulegé (within which the biosphere reserve is located) has had serious financial problems for at least the 
last five years. The Chief County Administrator (Alcalde de Mulegé), Guille Santillan, has claimed that he came into office in 2011 with a 55 million peso debt (US\$9.3 million) for the Mulegé municipality and at the time of writing, his office owed US\$20 million pesos in back salaries to more than 600 government employees (Gaxiola 2015). According to an informant, Santillan also claimed that his administration never received any funds from the salt mining company (around US\$12 million a year is owed) nor had he received any federal money from the 7.5\% tax on mines. Indeed, the salt company (the largest in the world) may be on the verge bankruptcy due to long-term mismanagement and embezzlement (Barragán 2015).

A second issue is the potential for collectively-held land within the Reserve to be privatized and sold to developers. Recent policy changes to the rules governing the privatization of communal land are intended to address rural poverty and claims that rural agricultural workers have been excluded from state benefits (Martinez-Reyes 2014). Unfortunately, selling land is one of the few ways that cash poor, land rich rural workers can generate capital. Indeed, seen through the lens of neoliberalism, a request made to the first author by an ejiditario from Ejido Benito Juárez to purchase his private parcels of land could be interpreted as a mechanism to enable elite land grabs.

Regarding this, an informant explained that in the Valle de Los Cirrios protected area (adjoining El Vizcaíno Biosphere Reserve) ejiditarios were (at the time of writing), negotiating the sale of thousands of hectares of pristine oceanfront land to an external tourism developer. They were doing this despite having knowledge of the poor outcomes generated by selling land in Cabo Pulmo National Park on the Baja California peninsula to the south. In that Reserve, politically active local residents (many of whom are North American expatriates) recently ran a successful campaign against a large-scale tourism development that would have threatened local livelihoods, lifestyles and protected marine ecologies (Anderson 2015).

\section{Discussion}

This Mexican case illuminates how the operations and outcomes of ecotourism are circumscribed by: (1) the misdirected interventions of external and state institutions; (2) the duplicitous actions of big-business development, and (3) opaque local governance with limited mechanisms for accountability and equity. In El Vizcaíno Biosphere Reserve, state policies that have reduced government involvement in the economy and encouraged private investment have challenged the small community of Ejido Benito Juárez in its efforts to achieve the sustainable economic future its inhabitants want. The success of the community in transitioning from farming to ecotourism has been stymied by the dishonest activities of the salt mining company and by internal political and social conflict. Moreover, an overriding problem for integrating conservation with development in the World Heritage site is the existence of mismanagement and corruption by the state and the private sector - problems that are less well-recognized in the literature. Inequitable local institutions and the commodification of the environment, together with poor environmental enforcement, are manifestations of neoliberalism at the local scale.

Although some commentators argue that conservation and development priorities may be irreconcilable (e.g. Minteer and Miller 2011), our findings support those of Fletcher (2012), and suggest that trade-offs that favour economic outcomes over social and ecological sustainability exacerbate inequities in access to resources, aided by ineffective and corrupt governance processes. We propose that the academic focus on neoliberalism at international/national scales has created what Hill et al. (2015) have described as an "attention deficit" of the on-the-ground outcomes of conservation policies and strategies at the local scale. Critically evaluating claims about the potential of in-situ resource use (such as ecotourism) to contribute to equitable socio-economic development necessitates closer attention to what is being sustained and who decides. We discuss these issues below through the lenses of top-down conservation and external actor influence, big-business and sustainable development, and institutional processes and conservation.

\section{External and state actor influence}

The working slogan of CONANP - 'with, for, and in favour of the people' - indicates an intention to include rural inhabitants in participatory development (CONANP 2014). Despite the rhetoric, conservation policy in El Vizcaíno Biosphere Reserve has been implemented with top-down processes (Castellanos et al. 
2002; Ortega-Rubio 2000). Exclusion began with the process leading to the Presidential decree for the Reserve in 1988. This should have involved consultation among local resource users, other economic sectors and conservation organizations regarding the purpose of the Reserve. However, as Castellanos et al. point out, "there was no social consensus on the El Vizcaíno Biosphere Reserve's purpose, especially concerning development and land allocation" (2002: 336). Although rural collectives own more than 85\% of the Reserve, in reality consensus has involved little more than "formal consultation with political representatives." The consensus process was described by those involved as "easy", because the region was seen as a "largely unpopulated" desert (Ortega-Rubio 2000: 4).

A history of top-down decision-making has tended to produce actions directed towards the interest of powerful external actors in El Vizcaíno Biosphere Reserve (Ortega-Rubio et al. 2001a). This is exemplified by the outcomes of a proposal made by the salt company fifteen years ago to expand salt mining operations into the relatively pristine San Ignacio Lagoon Whale Sanctuary $145 \mathrm{~km}$ (90 miles) south of the Ojo de Liebre Lagoon Whale Sanctuary (Spalding 2006). An environmental impact study prepared by a committee appointed by the Ministry of the Environment and Natural Resources (SEMARNAT) found that the salt company had complied with environmental laws and argued that the expansion would not impact whales and other species in the zone negatively (Ortega-Rubio et al. 2001a). The Centre for Biological Research of the Northeast, the state organization that wrote the Reserve management plan and the environmental impact statement was supported by municipal, state and federal politicians (Castellanos et al. 2002; Ortega-Rubio et al. 2001b). Mexican and international environmental conservation organizations, together with a local fishing ejido lobbied against the salt industry executives and government researchers. They challenged the orthodoxy of industrial capitalism - i.e. a development perspective based on harnessing natural resources in a remote and pristine World Heritage Site to make salt that supported the industrial development of Japan and other countries on the Pacific Rim (salt is a critical component in plastics manufacturing) (Spalding 2006).

After five years of intense lobbying of Mexico's President and intense pressure from international conservation organizations, supported by the endorsement of international celebrities, the saltworks proposal was finally cancelled by a Presidential decision in 2000 (Spalding 2006). Amidst enduring social and political resistance to the unilateral Presidential decision, a payment for ecosystem services (PES) subsidy scheme was then implemented to effect a land easement protecting the site from development (Spalding 2006). The outcome exemplifies the considerable power possessed by external actors to influence national environmental decision-making, including through savvy media manipulation embedded in moral protest (Bryant 2009; Fletcher 2009; MacDonald 2010).

While this example illustrates the power that external and state actors possess to generate conflict over access to, and use of, resources it also shows how, for Ejido Benito Juárez, ecotourism has brought mixedblessings. On the one hand, the fishing ejido successfully resisted the expansion of the saltworks. On the other, despite scaling-up resistance to build an effective international coalition against environmental despoliation, the payment for ecosystem services scheme did not produce sustained social and economic improvements at the local level. Although local ecologies were protected, socio-economic improvements did not follow. Studies elsewhere show that in many developing countries ecotourism has not lived up to expectations about its purported social and economic benefits (Fletcher and Neves 2012; Krüger 2005). Indeed, some scholars argue that limited local participation in decision-making and government subsidy schemes, such as PES, provide evidence that ecotourism has limited capacity to address poverty or remedy disparities in access to resources (Doane 2014; Fletcher and Breitling 2012).

\section{Big business and sustainable development}

Income generation from ecotourism in the study area competes with incomes derived from industrial capitalism, in the form of salt production, creating a variety of obstacles to sustainable development. As we have described above, the salt company appropriated land owned by Ejido Benito Juárez on the foreshores of the Ojo de Liebre lagoon to construct artificial ponds, where salt water could be evaporated to produce industrial salt. Although salt production began in the 1970s, concurrent with the founding of the ejido, it has taken more than five decades for the ejido to negotiate an agreement for the use of communal land. 
Moreover, we found some community members were deeply frustrated over what they perceive to be a relatively small payment.

Nonetheless, of the ejido's two primary sources of income, ecotourism and renting out of communal land, the latter is buffered against external shocks common to the tourism industry, particularly the variation in visitor numbers. While ecotourism returns are currently reduced for Ejido Benito Juárez, ejido members still receive income from the rental of communal land for salt production. However, the salt company's use of the ejido's land has imposed a kind of Faustian tyranny, by restricting the ejido's capacity to diversify into year-round ecotourism activities. Public access to the Ojo de Liebre Lagoon, without prior written permission, is restricted to a four month winter season. Tourists from North America usually come to the Baja California Peninsula during the winter. However, national and European tourists usually arrive during the spring and summer. In particular, national tourism is very strong during the Easter week. Yet, during Easter the gate on the access road to the Ojo de Liebre Lagoon is locked and guarded.

Why is there complacence over opening negotiations for year-round-access to the lagoon? The answer, in part at least, is related to the institutional characteristics of the ejido (discussed in the following section). Local institutions are not designed to ensure that ecotourism delivers equitable outcomes for the community. Moreover, community members who already benefit financially have little motivation to change existing arrangements.

Governments and external agents profess faith in the capacity of simple market-based strategies to achieve complex socio-natural outcomes. Yet, the close connection between social inequity, deteriorating environmental outcomes and market-friendly regulation (i.e. privatization) has been de-emphasized in conservation discourse; ecotourism has done little to reduce inequities in access to resources (Büscher and Davidov 2015; Krüger 2005). Ecotourism cannot substitute for the institutional reform that is needed to manage natural resources sustainably. Nor can it influence multinational corporations to engage in operational practices that could deliver better socio-economic outcomes for local communities and sustainable ecologies within the World Heritage site.

\section{Governance and neoliberal conservation}

Our findings suggest that the concerted actions of state agencies, external stakeholders and the characteristics of local institutional processes have paralysed the capacity for Ejido Benito Juárez to identify and act upon opportunities for developing sustainable livelihoods. The latter is surprising, as individual members of Ejido Benito Juárez are distinguished by their proactive behaviour to secure better economic futures. It is important to understand how and why political and institutional characteristics are generating this response.

We suggest that governance in Ejido Benito Juárez is both underpinned and undermined by institutionalized processes of participatory, economic and social exclusion. Resource management is through a governance system based on rigid membership rules and exclusionary processes for planning and problemsolving. The governance arrangements for Ejido Benito Juárez, as in ejidos elsewhere in Mexico, direct profits from the use of communal land to members. Ejido Benito Juárez comprises 90 members and of these 82 are men and just eight are women. Members own the land and have full rights in the ejidal Assembly, which is headed by a four person Board of Directors (president, secretary, treasurer and head of security) elected by members every three years. Non-members can participate in some common land management activities and contribute to the cost of maintaining equipment from which they benefit (e.g. water pumps). They do not vote in the Assembly, participate in decision-making processes, or receive income from use of communal land. The lack of women's participation in formal decision-making processes in El Vizcaíno Biosphere Reserve appears to affect resource use and conservation. This finding corroborates insights from what is now a fairly substantial body of research on gender and environmental governance (e.g. Agarwal 2009; Agrawal 2003; Rocheleau 2008). However, research on neoliberal conservation agendas and approaches specifically, has tended to downplay the role of gender in conservation outcomes, and more attention to conservation policy and its impacts on women is required (Buscher et al. 2014; Rocheleau 2008). 
If equitable participation is critical to achieving sustainable in-situ resource use (as conservation discourse now argues) then why do autonomous rural institutions fail to pursue legitimate and equitable processes for resource management? For example, there is a near absence of both female ejiditarios and female employees in the operations of the whale watching business, reflecting women's' subordinate positions in ejidal politics. Moreover by tolerating exclusionary practices, the practices of state agencies constrain some conservation initiatives. For example, there appears to be little enthusiasm from leaders to involve women in sustainable development planning. As noted previously, the ejidal assembly stymied initial excitement for an interpretive/recreation trail on the foreshores and inner waters of the Ojo de Liebre Lagoon. Two factors are salient. First, the ejido needs to negotiate with the salt company for permission for yearround-access to the lagoon. The director of the Casa Mexicana de la Ballena Gris said that the idea of seeking permission from the salt company has been talked about for many years, but has not been acted upon. Second, ejido leaders and administrators appear to be disinterested in the idea of using existing ecotourism infrastructure for community livelihood enhancement and community recreation opportunities. Indeed, an administrator claimed that it was probably only North American tourists who are interested in recreation activities such as kayaking, bike riding and camping.

In concert, the lack of attention to equitable decision-making processes, concern over maintaining the key source of income generation (the leasing of 16,000 ha/160 $\mathrm{km}^{2}$ of communal land for salt processing), and the potential for ejiditarios to cash in through permitted subdivision of communal land all highlight the inadequacy of simplistic notions of using integrated nature protection and nature commercialization to achieve socio-ecological objectives (see also Fletcher 2012; Lee 2014; Martinez-Reyes 2014). Our findings point to the need for political reform in protected area management to guarantee that sustainable development projects such as ecotourism actually generate a sustainable environmental, social and economic future for local communities. They also point to the need for institutional reforms to Mexico's land tenure system (the ejido) to ensure that decision-making processes about protected resources are open, transparent and accountable. Finally, we have shown the need for state policies that encourage the private sector to address interconnected environmental and social issues, not just one objective to the exclusion of the other. After all, the long-term viability of conservation areas like El Vizcaíno Biosphere Reserve depends upon meeting the social and economic needs of local communities as well as protection of the environment on which these communities depend.

\section{Conclusion}

The purpose of protected areas in the developing world is contested (Buscher et al. 2012). Competing objectives for ecosystem conservation versus utilization can generate conflict (e.g. in-situ vs. extractive resource use). In El Vizcaíno Biosphere Reserve, for example, we have found that regional economic development activities and the expansion of urban centres, continue to place additional pressure on buffer zones, creating ongoing challenges for strategic planning and effective natural resource management.

The diverse needs of people inhabiting and using these protected places, some of which are also World Heritage Sites, requires closer scrutiny from geographers and other nature-society researchers (Fletcher and Neves 2012). Serious empirical work addressing inequity as a core focus of nature-society interrelations must also contend with the technical issues attendant to conservation and spatial planning (Cronkleton et al. 2011). Contextualized research can help us better understand how diverse resource management strategies and the actions of diverse interest groups across multiple scales either achieve or frustrate conservation and development objectives (Hockings et al. 2013). But, as yet "little formal theory exists for how to explicitly incorporate equity into conservation planning and prioritization" (Halpern et al. 2013: 6229). Challenges are also associated with the diverse motives of international conservation organizations and their employees, many of whom regard multiple-use protected areas as particularly outstanding public amenities, but give little attention to the people inhabiting these places (Corson 2010; Walker et al. 2007).

This article has important implications for protected area management. Growing numbers of protected areas in Mexico are being designated and managed with the objective of providing better environmental protection and improved social benefits for local people (Haenn et al. 2014). However, as we have seen in 
this case example, management objectives for equitable and sustainable livelihoods can be readily eroded by the activities of big business, supported by governments (Anderson 2015; Martinez-Reyes 2014). Indeed, the neoliberalisation of conservation portends increased conflict within multiple-use protected areas worldwide especially those where urban expansion and industrial development are juxtaposed against in-situ 'sustainable' resource use.

In order to address these concerns, we need a better understanding of marginalization and the work it performs. Here, we have sought to refocus attention on interconnections between sustainable development objectives, the actions of neoliberal government, and the capacities and motivations of local people and institutions. We note that multiple-use protected areas in Mexico as elsewhere in the developing world are "open for "business". The Mexican government, motivated by neoliberal ideology, is seeking to forge stronger interdependencies among conservation organizations, funding bodies and state protected area agencies (Rodríguez et al. 2007). If multiple-use protected areas become fully co-opted by neoliberal agendas, "myriad forms" of socio-economic marginalization are likely (Brockington and Igoe 2006: 425; Büscher and Davidov 2015). Here we have examined the ecotourism-extraction nexus of whale ecotourism and salt mining, asking whether these two activities are compatible in the context of socio-ecological objectives for biosphere reserve management. We have shown how the divergent agendas of local and international actors can produce competing claims over nature - as imperiled ecosystem, valuable resource and/or source of local livelihoods - as well as unequal socio-ecological outcomes.

The question of compatibility can be answered in part by understanding the mechanisms of marginalization. Protected area managers must be cognizant not only of the deep-rooted social bias that is often found within the rural institutions of developing countries, but also of competing ideologies that underwrite harmful practices (Persha et al. 2011). We have found that the relationships between economic marginalization and political conflicts are complex. Individuals' experiences of the benefits of the protected area are strongly mediated through their encounters with state and local institutions, and mirror gender inequity and political corruption.

Building the institutional capacity of ejidos to remedy these inequities will require better incentives to overcome both entrenched discrimination (e.g. patriarchy) and the apathy of those members who benefit most from salt mining (Robbins 2004). In other words, concerted actions are needed from a range of stakeholders to facilitate the effective participation of marginalized social groups in political processes that support conservation and sustainable livelihoods. The Mexican state has played a pivotal role through top-down governance practices, the promotion of neoliberal ecotourism, and poor environmental enforcement. Our findings demonstrate that local compromises over access and social equity have been intense, and progress in addressing inequality has been slow. State-supported commodification of the environment has been a significant contributing factor to the slow progress in redressing socio-economic equity.

This conflicted role of the state as conservation manager and economic agent is inflected by a Mexican form of neoliberalism, or at least a local manifestation of it, adapted to the Mexican context. Breunig's (2008) work in the Baja California Peninsula has shown how the 'brand' of conservation practiced in neoliberal Mexico has stymied the growth of local groups that may otherwise have been able to fill the vacuum created by the retreat of the state from environmental management. Likewise, efforts to practice USstyle ecotourism in Mexico, through devolving responsibility to the 'shadow state' of conservation NGOs, has not worked (Romero Brito 2016). Ultimately, there must be better coordination among state agencies, external conservation agencies, private sector businesses, local collectives, and local citizens' groups to effect creative solutions to conservation and livelihood needs (Rocheleau 2008). A good example is how nature conservancies in India, have devised programs that utilize women's specific capabilities in promoting conservation and reducing inequality (Agarwal 2009; Agrawal 2003).

The different perspectives, knowledge, and preferences of women can potentially make a discernable difference to how the goals of integrated conservation and economic development play out. While there is now a substantial and important literature on the role of women's involvement in public decision-making and local environmental governance (e.g. Agarwal 2009; Platteau 2004), questions remain about how the gender composition of local collectives affects ecotourism/conservation management objectives (Igoe and Fortwangler 2007, Rocheleau 2008). Research is needed on, for example, the factors that configure the 
efficacy of women's participation in environmental governance (e.g. attending meetings, speaking at meetings and holding office) and how increasing the proportion of women in formal decision-making might shape alternative conservation outcomes.

In the introduction we noted a trend towards the increasing privatization of nature associated with the growing influence of neoliberal ideology (Castree 2010). Ecotourism enterprises, such as whale watching, are presented as an enlightened alternative to whaling (Neves 2010). Yet, our study highlights how ecotourism is being circumscribed by Mexico's land tenure institutions, the salt company, and misdirected interventions by the state and external actors. In El Vizcaíno Biosphere Reserve, environmental sustainability in the World Heritage site is an economic and political battle fought on multiple fronts. At the local community level, inhabitants are focused on meeting their immediate economic needs. At the state and national levels, stakeholders are prioritizing short-term economic growth over long-term social equity and the ecology. If this situation continues, the long-term sustainability of the World Heritage site will be compromised.

Our investigations were restricted to institutionalized forms of social exclusion, and the juxtaposition of industrial development and ecotourism operations, a theme that is under-examined in political ecology. Further research is needed on how the mining and ecotourism projects identified in our study are impacting the ecology of the World Heritage site. As yet, there is no biophysical or socio-cultural evidence that salt mining is compatible with conservation - just the opposite. Moreover, the Whale Sanctuary of El Vizcaíno World Heritage Site may also be at risk of replicating the unsustainable patterns of development seen elsewhere in Mexico (Haenn et al. 2014). Ecotourism cannot substitute for the genuine institutional reform that is required in protected area management to deliver outcomes that benefit local communities, enabling local people to pursue sustainable livelihood strategies and directly participate in the management of protected areas, thus achieving demonstrable improvements to both social wellbeing and environmental quality.

Given the manifold problems stemming from the compensation scheme agreed upon by the local community and the salt company, this relationship also needs further critical examination. There is an evident 'fetishism' in assigning arbitrary monetary value to environmentally risky economic activities, worsened where the playing field is blatantly uneven (Halpern et al. 2014). The compensation scheme also smacks of 'land grabbing'. Achieving both conservation and local economic development is only possible if measures are in place to redistribute power, enable local participation in decision-making and neutralize the undue influence of a multinational corporation on the local state. Future research should examine this issue. While such a task beyond the scope of this paper, we recognize there is fertile terrain here for extending and enhancing the scope of political ecology to interrogate the efficacy of the ecotourism-extraction nexus as but one option for local community development in protected areas, and hopefully to also highlight viable alternatives.

\section{References}

Adams, W.M. and J. Hutton. 2007. People, parks and poverty: political ecology and biodiversity conservation. Conservation and Society 5: 147-183.

Agarwal, B. 2009. Gender and forest conservation: the impact of women's participation in community forest governance. Ecological Economics 68: 2785-2799. Reseachgate

Agarwal, B. 2010. Does women's proportional strength affect their participation? Governing local forests in South Asia. World Development 38: 98-112.

Agrawal, A. 2003. Sustainable governance of common-pool resources: context, methods, and politics. Annual Review of Anthropology 32: 243-262. Researchgate

Agrawal, A. and A. Chhatre. 2007. State involvement and forest co-governance: evidence from the Indian Himalayas. Studies in Comparative International Development 42: 67-86. Researchgate

Agrawal, A. and C.C Gibson. 1999. Enchantment and disenchantment: the role of community in natural resource conservation. World Development 27: 629-649.

Anderson, R. 2015. Sustainability, ideology, and the politics of development in Cabo Pulmo, Baja California Sur, Mexico. Journal of Political Ecology 22: 239-254. 
Babb, S. 2004. Managing Mexico: economists from nationalism to neoliberalism. Princeton, NJ: Princeton University Press.

Bath, P. and A. Putney. 2010. Final independent evaluation of SINAP 2: the consolidation of the National System of Protected Areas ensuring core conservation activities in 12 globally important protected areas. Project appraisal document for the World Bank and Global Environment Facility Trust Fund.

Breunig, L.A. 2006. Conservation in context: establishing natural protected areas during Mexico 's neoliberal reformation. Ph.D. dissertation. Tucson: University of Arizona.

Brockington, D., R. Duffy and J. Igoe. 2008. Nature unbound: conservation, capitalism and the future of protected areas, London: Earthscan.

Brockington, D. and J.Igoe. 2006. Eviction for conservation: a global overview. Conservation and Society 4: 424-470.

Brockington, D. J. Igoe, and K. Schmidt-Soltau. 2006. Conservation, human rights, and poverty reduction. Conservation Biology 20: 250-252.

Bryant, R.L. 2009. Born to be wild? Non-governmental organisations, politics and the environment. Geography Compass 3: 1540-1558.

Büscher, B. and V. Davidov. 2016. Environmentally induced displacements in the ecotourism-extraction nexus. Area 48(2): 161-167.

Büscher, B. and R, Fletcher. 2015. Accumulation by conservation. New Political Economy 20: 273-298.

Campbell, L.M., B.J. Haalboom and J. Trow. 2007. Sustainability of community-based conservation: sea turtle egg harvesting in Ostional (Costa Rica) ten years later. Environmental Conservation 34: 122131.

Castellanos, A., L. Arriaga and C. López. 2002. El Vizcaíno Biosphere Reserve: a case study of conservation and development in Mexico. Natural Areas Journal 22: 331-339.

Castree, N. 2010. Neoliberalism and the biophysical environment 1: what 'neoliberalism' is, and what difference nature makes to it. Geography Compass 4: 1725-1733.

CONANP. 2014. Programa Nacional de Áreas Naturales Protegidas: 2014-2018. México, D.F.: CONANP.

Corson, C. 2010. Shifting environmental governance in a neoliberal world: US AID for conservation. Antipode 42: 576-602.

Cronkleton, P., D.B. Bray and G. Medina. 2011. Community forest management and the emergence of multiscale governance institutions: lessons for REDD+ development from Mexico, Brazil and Bolivia. Forests 2: 451-473.

del Río, I. and M.R. Altable Fernández. 2011. Breve historia de Baja California Sur. Mexico D.F.: Colegio de México y Fideicomiso Historia de las Américas.

Doane, M. 2014. From community conservation to the lone (forest) ranger: accumulation by conservation in a Mexican forest. Conservation and Society 12: 233-244.

Duffy, R. 2013 A trip too far: ecotourism, politics, and exploitation. London: Earthscan.

Durand, L., F. Figueroa and T. Trench. 2014. Inclusion and exclusion in participation strategies in the Montes Azules Biosphere Reserve, Chiapas, Mexico. Conservation and Society 12: 175-189.

Fletcher, R. 2009. Ecotourism discourse: challenging the stakeholders theory. Journal of Ecotourism 8: 269285. Researchgate

Fletcher, R. 2012. Using the master's tools? Neoliberal conservation and the evasion of inequality. Development and Change 43: 295-317. Researchgate

Fletcher, R. and J. Breitling. 2012. Market mechanism or subsidy in disguise? Governing payment for environmental services in Costa Rica. Geoforum 43: 402-411. Researchgate

Fletcher, R. and K. Neves. 2012. Contradictions in tourism: the promise and pitfalls of ecotourism as a manifold capitalist fix. Environment and Society: Advances in Research 3: 60-77. Researchgate

Gaxiola, I. 2015. No me escondí, estaba gestionando: Guillermo Santillán, alcalde de Mulegé. BCS Noticias. La Paz, Baja California Sur: Gobierno de Baja California Sur. 
Haenn, N., E. Olson, J. Martinez-Reyes and L. Durand. 2014. Introduction: between capitalism, the state, and the grassroots: Mexico's contribution to a global conservation debate. Conservation and Society 12: 111-119.

Halpern, B.S., C.J. Klein, C.J. Brown, M. Begerc, S. Hedley, H.S. Grantham, S. Mangubhai, M. Ruckelshaus, V.J. Tulloch, M Watts, C. White and H.P. Possingham. 2013. Achieving the triple bottom line in the face of inherent trade-offs among social equity, economic return, and conservation. Proceedings of the National Academy of Sciences 110: 6229-6234.

Hastings, J. 2015. Building participation in large-scale conservation: lessons from Belize and Panama. Conservation and Society 13: 221-231.

Heynen, N., J. McCarthy, S. Prudham and P. Robbins (eds.). 2007. Neoliberal environments: false promises and unnatural consequences. London: Routledge.

Heynen, N. and P. Robbins. 2005. The neoliberalization of nature: governance, privatization, enclosure and valuation. Capitalism Nature Socialism 16: 5-8. Researchgate

Hill, W., Byrne, J. and C. Pickering. 2015. The 'hollow-middle': why positive community perceptions do not translate into pro-conservation behaviour in El Vizcaíno Biosphere Reserve, Mexico. International Journal of Biodiversity Science, Ecosystem Services and Management 11: 168-183. Researchgate

Hirsch, P.D., W.M. Adams, J.P. Brosius, A. Zia, N. Bariola and J.L. Dammert. 2011. Acknowledging conservation trade-offs and embracing complexity. Conservation Biology 25: 259-264.

Hockings, M., W.M. Adams, T.M. Brooks, N. Dudley, H. Jonas, W. Lotter, V. Mathur, R. Väisänen and S. Woodley. 2013. A draft code of practice for research and monitoring in protected areas. Parks 19: 8594.

Hoffman, D. 2014. Conch, cooperatives, and conflict: conservation and resistance in the Banco Chinchorro Biosphere Reserve. Conservation and Society 12: 120-132.

Hunt, C.A, W.H. Durham, L. Driscoll and M.Honey. 2015. Can ecotourism deliver real economic, social, and environmental benefits? A study of the Osa Peninsula, Costa Rica. Journal of Sustainable Tourism 23: 339-357. Researchgate

Igoe, J. and B. Croucher. 2007. Conservation, commerce, and communities: the story of community-based wildlife management areas in Tanzania's northern tourist circuit. Conservation and Society 5: 534561.

Igoe, J. and C. Fortwangler. 2007. Whither communities and conservation? International Journal of Biodiversity Science, Ecosystems Services and Management 3: 65-76. Researchgate

INE. 2000. Programa de manejo reserva de la Biosfera El Vizcaíno México, D.F.: Instituto Nacional de Ecología y Secretaría de Medio Ambiente, Recursos Naturales y Pesca.

Krüger, O. 2005. The role of ecotourism in conservation: panacea or Pandora's box? Biodiversity and Conservation 14: 579-600.

Lee, A.E. 2014. Territorialisation, conservation, and neoliberalism in the Tehuacán-Cuicatlán Biosphere Reserve, Mexico. Conservation and Society 12: 147-161.

MacDonald, K.I. 2010. Business, biodiversity and new 'fields' of conservation: the world conservation congress and the renegotiation of organisational order. Conservation and Society 8: 256-275.

Martinez-Reyes, J. 2014. Beyond nature appropriation: towards post-development conservation in the Maya Forest. Conservation and Society 12: 162-174.

McAfee, K. and E.N. Shapiro. 2010. Payments for ecosystem services in Mexico: nature, neoliberalism, social movements, and the state. Annals of the Association of American Geographers 100: 579-599.

McShane, T.O., P.D. Hirsch, T.C. Trung, A.N. Songorwa, A. Kinzig, B. Monteferri, D. Mutekanga, H.V. Thang, J,L. Dammert, M. Pulgar-Vidal, M. Welch-Devine, J.P. Brosius, P. Coppolillo and S. O’Connor. 2011. Hard choices: making trade-offs between biodiversity conservation and human wellbeing. Biological Conservation 144: 966-972. 
Minteer, B.A. and T.R. Miller. 2011. The new conservation debate: ethical foundations, strategic trade-offs, and policy opportunities. Biological Conservation 144: 945-947.

Mostafanezhad, M., R. Norum, E. Shelton and A. Thompson-Carr (eds.). 2015. Political ecology of tourism: community, power and the environment. Abingdon, Oxon: Routledge.

Nepal, S. and J. Saarinen (eds.). 2015. Political ecology and tourism. Abingdon, Oxon: Routledge.

Neves, K. 2010. Cashing in on cetourism: a critical ecological engagement with dominant E-NGO discourses on whaling, cetacean conservation, and whale watching. Antipode 42: 719-741. Researchgate

Ortega-Rubio, A. 2000. The obtaining of biosphere reserve decrees in Mexico: analysis of three cases. The International Journal of Sustainable Development and World Ecology 7: 217-227.

Ortega-Rubio, A., D.B. Lluch-Cota, and A. Castellanos-Vera. 2001a. Salt production at San Ignacio Lagoon: a sustainable development project? The International Journal of Sustainable Development \& World Ecology 8: 155-165.

Ortega-Rubio, A., D.B. Lluch-Cota, and A. Castellanos. 2001b. Discrepancies in an environmentally controversial salt production project: local versus national and international perceptions. Ambio 30: 64-65.

Peck, J. and A. Tickell. 2002. Neoliberalizing space. Antipode 34: 380-404.

Pegas, F.dV. and J.G. Castley. 2014. Ecotourism as a conservation tool and its adoption by private protected areas in Brazil. Journal of Sustainable Tourism 22: 604-625.

Pegas, F.dV., A. Coghlan, A. Stronza and R. Rocha. 2013. For love or for money? Investigating the impact of an ecotourism programme on local residents' assigned values towards sea turtles. Journal of Ecotourism 12: 90-106. Researchgate

Perreault, T. and P. Martin. 2005. Geographies of neoliberalism in Latin America. Environment and Planning A 37: 191-201.

Persha, L., A. Agrawal, and A. Chhatre. 2011. Social and ecological synergy: local rulemaking, forest livelihoods, and biodiversity conservation. Science 331: 1606-1608. Academia

Platteau, J.P. 2004. Monitoring elite capture in community-driven development. Development and Change 35: 223-246.

Robbins, P. 2004. Political ecology: a critical introduction. Oxford: Blackwell. Ch.1

Rocheleau, D. and R. Roth. 2007. Rooted networks, relational webs and powers of connection: rethinking human and political ecologies. Geoforum 38: 433-437. Researchgate

Rocheleau, D.E. 2008. Political ecology in the key of policy: from chains of explanation to webs of relation. Geoforum 39: 716-727.

Rodríguez, J., A. Taber, P. Daszak, R. Sukumar, C. Valladares-Padua, S. Padua, L.F. Aguirre, R.A. Medellín, M. Acosta, A.A. Aguirre, C. Bonacic, P. Bordino, J. Bruschini, D. Buchori, S. González, T. Mathew, M. Méndez, L. Mugica, L.F. Pacheco, A.P. Dobson and M. Pearl. 2007. Globalization of conservation: a view from the South. Science 317: 755-756.

Romero Brito, T. 2016. Non-governmental organisations (NGOs) in ecotourism. Ph.D. Dissertation, Griffith School of Environment and Griffith Sciences. Gold Coast: Griffith University.

Soederberg, S., G. Menz, and P.G. Cerny (eds.). 2005. Internalizing globalization: the rise of neoliberalism and the decline of national varieties of capitalism. London: Palgrave Macmillan.

Spalding, M.J. 2006. Mobilizing across borders: the case of the Laguna San Ignacio saltworks project. Working Paper Series, Issue Number 9. Justice in Mexico Project. La Jolla and San Diego: UCSD Center for U.S.-Mexican Studies and USD Trans-Border Institute.

Sproule, W. 2006. Content analysis. In Walter, M. (ed.) Social research methods: an Australian perspective. South Melbourne: Oxford University Press. 113-133.

Sundberg, J. 2004. Identities in the making: conservation, gender and race in the Maya Biosphere Reserve, Guatemala. Gender, Place and Culture 11: 43-66. 
Teichman, J. 2008. Redistributive conflict and social policy in Latin America. World Development 36: 446460.

UK Telegraph 2012. Gray whale watching on the Sea of Cortez in Mexico. [Accessed November 10, 2015]. [Accessed October 12, 2015]. http://www.telegraph.co.uk/travel/safariandwildlifeholidays/9058816/Baja-California-Mexicosplayground-for-whales.html

Valov, D. 2013a. Salt mining barge in the Ojo de Liebre Lagoon in El Vizcaíno Biosphere Reserve, Mexico. Colour photograph.

Valov, D. 2013b. Gray whale watching in the Ojo de Liebre Lagoon in El Vizcaíno Biosphere Reserve, Mexico. Colour photograph.

Van Wynsberghe, R. and S. Khan. 2007. Redefining case study. International Journal of Qualitative Methods 6: 80-94.

Veal, A.J. 2011. Research methods for leisure and tourism: a practical guide. Harlow: Pearson Education.

Walker, D., J.P. Jones III, S.M. Roberts and O.R. Fröhling. 2007. When participation meets empowerment: the WWF and the politics of invitation in the Chimalapas, Mexico. Annals of the Association of American Geographers 97: 423-444. Researchgate

Wells, M.P, and T.O. McShane. 2004. Integrating protected area management with local needs and aspirations. Ambio 33: 513-519. Researchgate

West, P., J. Igoe, and D. Brockington. 2006. Parks and peoples: the social impact of protected areas. Annual Review of Anthropology 35: 251-277. Researchgate

Worboys, G., M. Lockwood, A. Kothari, S. Feary and I. Pulsford (eds.) 2015. Protected area governance and management. Canberra: ANU Press.

Young, E.H. 1999. Balancing conservation with development in small-scale fisheries: is ecotourism an empty promise? Human Ecology 27: 581-620. 